\title{
ERGO - EVALUATION OF URBAN BUS DRIVER'S WORKSTATIONS IN SOUTH WEST NIGERIA
}

\author{
Salami O. Ismaila ${ }^{1}$, ORCID: 0000-0002-9875-8594, \\ Samson A. Odunlami², ORCID: 0000-0002-4838-6542, \\ Sidikat I. Kuye ${ }^{3}$, ORCID: 0000-0002-0286-1539, \\ Adekunle I. Musa 4*, ORCID: 0000-0002-4998-507X, \\ Adeniyi Olayanju ${ }^{5}$, ORCID: 0000-0002-4771-1171 \\ 1,3 Department of Mechanical Engineering, Federal University of Agriculture Abeokuta, Nigeria \\ ${ }^{2}$ Department of Mechanical Engineering, Federal Polytechnic, Ilaro, Nigeria \\ ${ }^{4}$ Department of Mechanical Engineering, Moshood Abiola Polytechnic,, Abeokuta, Nigeria \\ ${ }^{5}$ Department of Agricultural and Bio-Resources Engineering, landmark University, Omu Aran. Nigeria \\ ${ }^{*}$ Corresponding author: Adekunle I. Musa, musa.adekunle@mapoly.edu.ng
}

Received: 28.03.2021

Accepted: 20.04.2021

\begin{abstract}
This study evaluated the ergonomic performance of drivers' workstations in southwest Nigeria. Fifty urban buses selected from ten brands were investigated by direct measurement. The buses were mini-A and midi-B. Vertical and horizontal distances of the seat reference point to the pedal and steering wheel, with the seat dimensions were considered. The anthropometric dimensions of 150 male bus drivers were taken from South-west Nigeria. The results revealed that the values for driver's seat height from the cabin floor, seat backrest height, seat shoulder level width and low back width were 44.00$50.00 \mathrm{~cm}, 53.00-58.15 \mathrm{~cm}, 40.00-50.00 \mathrm{~cm}$ and $-40.15 \mathrm{~cm}$ respectively as against $39.15-$ $43.00 \mathrm{~cm}, 38.75-49.49 \mathrm{~cm}, 34.60-43.59 \mathrm{~cm}$ and $45.73-53.25 \mathrm{~cm}$ respectively in the urban bus workstations. It is concluded that the drivers' workstations in the urban buses were not ergonomically fit for the bus drivers since the anthropometric dimension of the Nigerian male bus drivers were not considered in the designing of the buses.
\end{abstract}

Keywords: Anthropometric, Ergonomics, Workstation, Drivers', Urban, Buses, Nigeria.

\section{Introduction}

The focus of the ergonomics approach is that the interaction between humans and other elements of a system and therefore the workstation so as to enhance efficiency, safety, and human well-being [1]. Several studies have confirmed that operators are readily available and more productive when their working environments are designed for his or her best performance [2, 3]. Where work tasks and equipment don't preclude ergonomic principles in their designs, workers are susceptible to be exposed to undue physical stress, strain, and overexertion, like an excessive amount of vibration, awkward working postures, forceful exertions, repetitive motion and work during a bid to correct and reduce hazards thereby improving worker's protection, it's very essential to acknowledge the ergonomic 
risk factors within the workplace. Therefore, ergonomists first consider human needs, his abilities and limitations as priorities when designing and evaluating tasks, jobs, products, environments and systems.

Proper ergonomic design is therefore necessary to stop repetitive strain injuries, which may develop over time and may cause a long-term or permanent disability. Ergonomic designs also consider the entire work system. it's widely applied in the areas of aviation, other transport systems, sport, education, public facilities, home, recreational equipment and facilities within the workplaces respectively. Really, all aspects of human endeavor enjoy ergonomic designs [4]. Anthropometric data may be a collection of the size of the physical body and is beneficial for attire sizing, forensics, physical anthropometry and ergonomic design of the workplace [5]. Similarly, some authors defined anthropometric data as that utilized in ergonomics to specify the physical dimensions of workplace, equipment, furniture and clothing $[6,7]$.

Byran et al., [8] acknowledged that so as to hold out the varied given tasks; the driving force has got to operate the vehicle controls during a sedentary posture. Controls like hand-controls and pedals are often described in terms of human outputs so as to regulate the vehicle. The hands are widely used for steering controls and various lever controls like gear and hand-brake controls. The hands also are wont to manipulate other controls like joystick controls (found in tractors) and delicate switch controls. The feet are used mostly to supply outputs for longitudinal vehicle control like acceleration or brake pedals. The sedentary posture has been acknowledged throughout the professional literature as problematic, as a serious risk factor and a contributor within the development of musculoskeletal disorders [8].

$\mathrm{Li}$ and Haslegrave [9], suggested that posture needs special attention during the planning process, especially when amid other manual manipulations that involve the utilization of force. The extra operations often cause adopting inadequate, un- comforted or 'bad' body postures, resulting on high risk of musculoskeletal disorder or maybe physical injury. The anthropometric study suggests an evaluation of all physical elements inside the cabin. The evaluation checks the geometric location, dimension, angel, and position of each element, in reference to each other and in reference to the Seat point of reference (SRP). Additionally, the study evaluates the geometric location of all controls (foot and hand), and displays, inside the cabin, to best fit the operators' anthropometry. It also evaluates the controls for his or her location with the utilization of force [8].

The influence of various forces and vibrations transmitted to the physical body through the seat during the drive shows a particular importance because they inflict a state of tiredness, especially to the driving force that makes a further effort as compared to other occupants [10]. It was reported that within the design of mobile equipment, a balance driver's seat usually reduces the ill effect of vibration within the vertebral column of the operators [11]. He concluded that care must therefore be taken in designing tractors and particularly tractor seats, to scale back vibration and shock to a minimum also as ensure comfortable posture. Driving postures employed by bus drivers should also take into consideration musculoskeletal and biomechanical factors, and make sure that all driving tasks are conducted within a cushy reach range. The posture of the seated person depends on the planning of the seat itself, individual sitting habits and therefore the work to be performed. Seated person depends on the planning of the seat itself, individual sitting 
habits and therefore the work to be performed. Seated postures are defined because the body position during which the load of the body is transferred to a supporting area.

The biomechanical considerations of seated postures include the spine, arms, and legs. The muscles at the rear of the thighs influence the relative position of the spine and pelvis, the situation and slope of the work area influence the position of the neck, shoulders, and upper extremities, when a private is during a seated posture. Tan et al., [12], reiterated that comfort is an attribute that today's drivers demand more and more; while seat is one among the important features of auto where the professional driver spends most of their time. Therefore, truck seat, which are in touch with truck occupants, play a crucial role in improving the comfort and work environment of a driver.

However, Tan et al., [12] in their research acknowledged that there's a huge majority of objective measures used for evaluating comfort and discomfort. From their literature search, they identified the target measurement methods for seat like pressure distribution, posture analysis, CAD (CAD), computer aided engineering (CAE), temperature, humidity, Oxygen saturation, vibration, Spinal Loading, electromyography (EMG), and adrenaline. Nigerian bus drivers always complain of undue stresses and extreme body pains during and after work. This, however, might be thanks to some preventable factors like the planning of the drivers' workstations which could not properly fit into the physical nature of the drivers; thereby forcing them to figure in awkward positions and conditions.

Ajayeoba and Adekoya [13], says that the optimum seat for one vehicle may not be the optimum seat for another vehicle and that most of the automotive seats, especially bus driver seats, were not designed according to the anthropometric data of Nigerians. Adekoya and Ajayeoba [14], noted that little work has been done in the area of functional design relationships which are significantly useful in the bus operator workstation. The objectives of this research work is to collect relevant design data from the drivers' compartments and seats of the selected urban buses and the anthropometric data of the Nigerian drivers of urban buses in South-Western Nigeria.

\section{Methodology}

\section{Collection of anthropometric and workstation variables}

In this study, 30 anthropometric variables of 150 professional male drivers, randomly selected from seven urban centers (Abeokuta, Ilaro, Sagamu, ljebu-ode, Oshodi, Yaba, Ibadan and Oyo) in three states (Lagos, Ogun and Oyo states) in South -West Nigeria were collected.

Similarly, 50 urban buses in two categories were considered. Category 'A' comprises of 6 common brands of urban mini buses with various capacities (MITSUBISHI - 10 seaters and 14 seaters, TOYOTA- COASTER- 30 seaters, MAZDA - 10seaters, HONDA - ODDYSEY 10seater and NISSAN - URVAN 14- seaters). Category 'B' consists of 4 common brands of midi buses (FOTON - 42 seaters, ASHOK - 42 seaters, TATA - 42 seaters and COMIL - 54 seaters). Measurement of the workstation parameters and the seat dimensions in all selected buses were done.

Measuring Instruments used are, Digital Stadiometer, PD 300M (DETECTO); Manufactured by Cardinal Scale Manufacturing Company, UK (figure 1), Digital Vernier Caliper - 600mm (figure 2) manufactured by Mitutoyo Corporation, Japan. A 3.5m Steel tape (figure 3); manufactured by Komelon, U.K was also used for this work and Bevel Protractor (figure 4). The Universal Bevel Protractor was manufactured by Mitutoyo Corporation, Japan. 


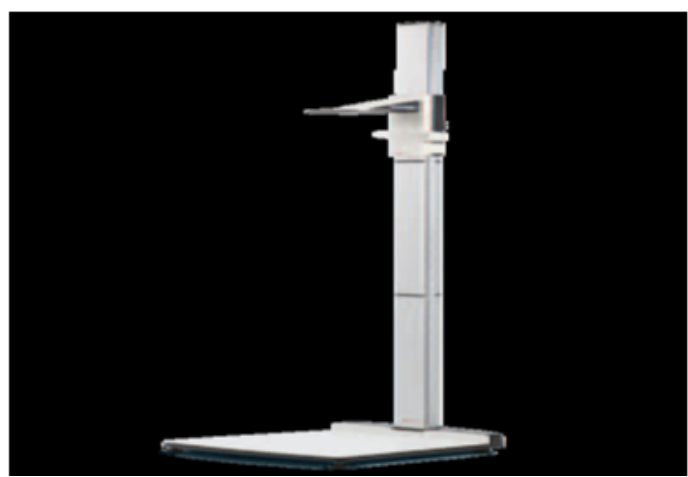

Figure 1. Standiometer.

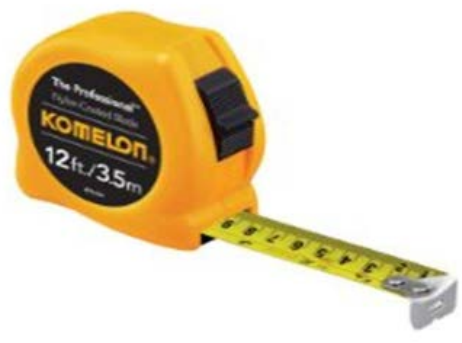

Figure 3. Steel Tape.

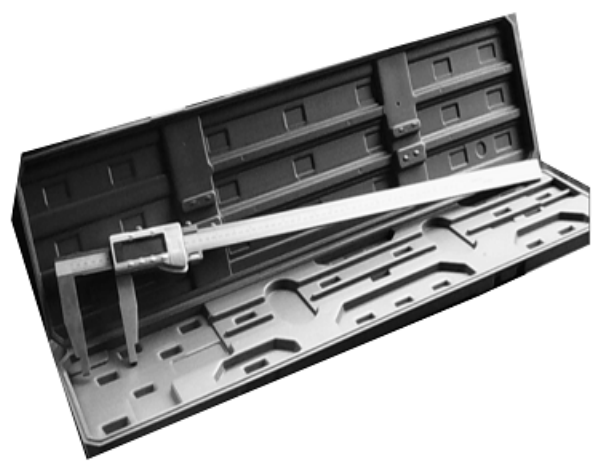

Figure 2. Digital Vernier caliper $(600 \mathrm{~mm})$.

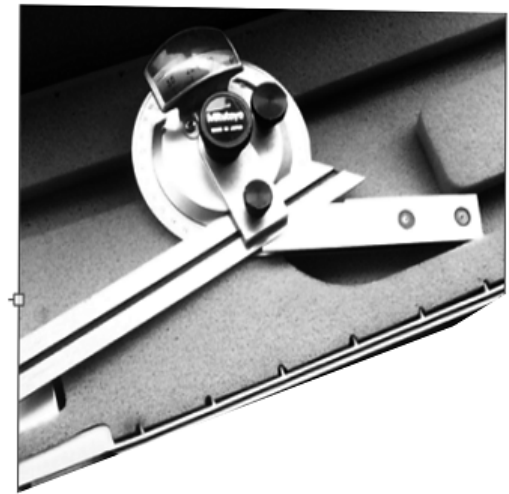

Figure 4. Universal bevel Protractor.

\section{Measurement of the Driver's Seat Variables:}

Preliminary search was conducted to identify the available brands of urban buses found to be commonly used in South-west Nigeria. These include: Toyota, Mazda, Mitsubishi, Nissan, and Honda. Observations together with direct linear and angular measurement were also carried out on the sampled drivers' seats.

The physical measurements of seat variables that were carried out on the sampled buses include: Seat height, Seat depth, Seat width, Headrest height, Headrest width, Backrest height, Backrest width (Lumber level), Backrest width (Thoracic level), Headrest angle, Backrest angle, and Armrest height/length (where available).

Table 1

\section{Anthropometric Dimensions collection}

Anthropometric parameters of urban bus drivers and their relevance

\begin{tabular}{lll}
\hline P. No. & PARAMETER (P) & RELEVANCE \\
\hline P1 & Stature & Cabinet Total Height \\
P2 & Sitting Height & Seat Backrest Height \\
P3 & Eye to Floor & Seatpan Height from Cabin Floor \\
P4 & Shoulder width & Seat Backrest (shoulder level) Width \\
P5 & Shoulder Height & Seat Backrest Height \\
P6 & Shoulder to Elbow & Armrest placement Height \\
P7 & Knee Height & Steering Wheel Height from floor \\
P8 & Popliteal Height & Seat Height and Pedal placement \\
P9 & Foot Length & Pedal placement from SRP \\
\hline
\end{tabular}


Continuation Table 1

\begin{tabular}{lll}
\hline P10 & Foot Width & Pedal width \\
P11 & Hand Length & Steering wheel rim thickness \\
P12 & Hand Width & Armrest surface width \\
P13 & Chest Width & Steering wheel diameter \\
P14 & Elbow angle with Steering & Steering wheel Distance from SRP \\
P15 & Elbow angle with gear & Gear-lever Distance from SRP \\
P16 & Popliteal angle (leg on floor) & Placement of Pedal \\
P17 & Foot angle (leg on pedal) & Placement of Pedal \\
P18 & Back angle (Sitting) & Placement of Steering wheel \\
P19 & Hip Width & Seatback/backrest width \\
P20 & Stomach Depth & Steering wheel placement \\
P21 & Knee Length & Seat distance from Steering rack \\
P22 & Head Width & Headrest width \\
P23 & Head Height & Headrest height \\
P24 & Stomach to steering & Steering rack placement \\
P25 & Popliteal Length & Seat Depth \\
P26 & Elbow to wrist & Steering wheel placement/armrest \\
P27 & Chest to steering wheel & Steering wheel placement \\
P28 & Knee to dashboard & Placement of seat from dashboard \\
P29 & Knee to steering rack & Placement of seat \\
P30 & Arm length & Placement of Steering wheel \\
\hline
\end{tabular}

\section{Statistical Data Analysis}

Data collected were analyzed using Microsoft Excel Starter 2010 and SPSS 16 to obtain the mean, standard deviation, $5^{\text {th }}, 50^{\text {th }}, 75^{\text {th }}$ and $95^{\text {th }}$ percentile for this research work.

\section{Results and Discussions}

\section{Data Obtained from Workstations}

The Seat Reference Point (SRP) was used for the placement of the two controls. The following tables present the results of the statistical analysis of the data collected during the field work.

Table 2

Summary of data obtained from mini bus workstations (Category A)

\begin{tabular}{|c|c|c|c|c|c|c|c|c|}
\hline $\mathrm{S} / \mathrm{N}$ & VARIABLE & No. & STD. DEV & MEAN & $\begin{array}{c}5^{\text {th }} \\
\text { Percentile }\end{array}$ & $\begin{array}{c}50^{\text {th }} \\
\text { Percentile }\end{array}$ & $\begin{array}{c}75^{\text {th }} \\
\text { Percentile }\end{array}$ & $\begin{array}{c}95^{\text {th }} \\
\text { Percentile }\end{array}$ \\
\hline 1 & Cabin Height & 30 & 13.39278 & 142.1667 & 122 & 148 & 149.5 & 150.75 \\
\hline 2 & Cabin width & 30 & 6.531973 & 92.66667 & 90 & 90 & 90 & 102 \\
\hline 3 & Cabin Length & 30 & 2.316607 & 90.16667 & 87.25 & 90.5 & 91.75 & 92.75 \\
\hline 4 & Seat to Door dist. & 30 & 3.444803 & 5.333333 & 3 & 4 & 5.5 & 10.5 \\
\hline 5 & Cabin floor to road & 30 & 16.54086 & 59 & 36.5 & 61.5 & 67.5 & 77.25 \\
\hline 6 & Pedal to Seat & 30 & 4.490731 & 42.83333 & 38.5 & 41.5 & 45.25 & 49 \\
\hline 7 & Steering to Floor & 30 & 4.119061 & 66.83333 & 61 & 68.5 & 70 & 70 \\
\hline 8 & $\begin{array}{l}\text { Dashboard- } \\
\text { backrest }\end{array}$ & 30 & 10.65364 & 77.5 & 62.5 & 79.5 & 81.5 & 88 \\
\hline 9 & $\begin{array}{l}\text { Steering to } \\
\text { backrest }\end{array}$ & 30 & 3.577709 & 45 & 40.5 & 45.5 & 46.75 & 49.25 \\
\hline 10 & dashboard width & 30 & 6.531973 & 92.66667 & 90 & 90 & 90 & 102 \\
\hline 11 & Dashboard height & 30 & 7.339391 & 41.66667 & 32 & 42.5 & 44.5 & 50.25 \\
\hline
\end{tabular}


Continuation Table 2

\begin{tabular}{|c|c|c|c|c|c|c|c|c|}
\hline 12 & $\begin{array}{l}\text { Steering wheel } \\
\text { Dia }\end{array}$ & 30 & 4.722288 & 40.5 & 38 & 38.5 & 39.75 & 47.5 \\
\hline 13 & $\begin{array}{l}\text { Steering rim } \\
\text { thickness }\end{array}$ & 30 & 0.917424 & 3.583333 & 2.625 & 3.5 & 4 & 4.75 \\
\hline 14 & Pedal angle & 30 & 2.581989 & 46.66667 & 45 & 45 & 48.75 & 50 \\
\hline 15 & $\begin{array}{l}\text { Steering rack } \\
\text { angle }\end{array}$ & 30 & 2 & 64 & 61 & 65 & 65 & 65 \\
\hline 16 & Door width & 30 & 9.287985 & 113.3333 & 101.25 & 116 & 120 & 122.25 \\
\hline 17 & Door height & 30 & 5.776389 & 134.8333 & 127 & 135 & 139 & 140.75 \\
\hline 18 & Dashboard to Seat & 30 & 8.140434 & 26.33333 & 14.5 & 29 & 30 & 31.5 \\
\hline 19 & Gear lever to Seat & 30 & 5.329165 & 16 & 10 & 16.5 & 19.5 & 22.25 \\
\hline 20 & Bus total Height & 30 & 30.06271 & 194.1667 & 162 & 190 & 197.5 & 235.25 \\
\hline 21 & $\begin{array}{l}\text { Steering rack to } \\
\text { Seat }\end{array}$ & 30 & 13.60392 & 23.33333 & 9.5 & 21.5 & 24.25 & 42.25 \\
\hline 23 & SRP-STR(H) & 30 & 5.785038 & 50.66667 & 42.5 & 51.5 & 54.5 & 55.75 \\
\hline 24 & SRP-STR(V) & 30 & 2.44949 & 32 & 30 & 31 & 34.25 & 35 \\
\hline 25 & SRP-PDL(H) & 30 & 3.32666 & 91.66667 & 87.25 & 93 & 93.75 & 94.75 \\
\hline 26 & SRP-PDL(N) & 30 & 2.316607 & 27.16667 & 25 & 26.5 & 29.25 & 30 \\
\hline
\end{tabular}

Table 3

Summary of data obtained from mini bus Drivers' Seats (category A)

\begin{tabular}{|c|c|c|c|c|c|c|c|c|}
\hline $\mathrm{S} / \mathrm{N}$ & VARIABLE & No. & STD. DEV & MEAN & $\begin{array}{c}5^{\text {th }} \\
\text { Percentile }\end{array}$ & $\begin{array}{c}50^{\text {th }} \\
\text { Percentile }\end{array}$ & $\begin{array}{c}75^{\text {th }} \\
\text { Percentile }\end{array}$ & $\begin{array}{c}95^{\text {th }} \\
\text { Percentile }\end{array}$ \\
\hline 1 & Floor to Seat & 30 & 6.08824 & 32.66667 & 25.5 & 33.5 & 34.75 & 40.25 \\
\hline 2 & Seat front width & 30 & 1.966384 & 50.33333 & 48.5 & 50 & 50 & 53 \\
\hline 3 & Seat back width & 30 & 2.75681 & 41 & 38 & 41 & 43.5 & 44 \\
\hline 4 & Seatpan depth & 30 & 0.516398 & 49.66667 & 49 & 50 & 50 & 50 \\
\hline 5 & Backrest width (Lumbar) & 30 & 2 & 49 & 47 & 49 & 50 & 51.5 \\
\hline 6 & Backrest width (thoracic) & & 2.258318 & 44.5 & 42.25 & 44 & 45.75 & 47.5 \\
\hline 7 & Backrest Height & 30 & 3.141125 & 53.66667 & 50 & 54.5 & 55 & 57.25 \\
\hline 8 & Headrest width & 30 & 4.086563 & 26.5 & 22 & 25.5 & 28.25 & 32 \\
\hline 9 & Headrest height & 30 & 8.438009 & 23 & 16 & 22 & 22.75 & 35 \\
\hline 10 & Armrest Length & 30 & & 30 & 30 & 30 & 30 & 30 \\
\hline 11 & Armrest width & 30 & & 7 & 7 & 7 & 7 & 7 \\
\hline 12 & Armrest thickness & 30 & & 8 & 8 & 8 & 8 & 8 \\
\hline
\end{tabular}

Table 4

\section{Summary of data obtained from midi bus workstations (category B)}

\begin{tabular}{|c|c|c|c|c|c|c|c|c|}
\hline $\mathrm{S} / \mathrm{N}$ & VARIABLE & No. & STD. DEV & $\operatorname{MEAN}(\mathrm{cm})$ & $\begin{array}{l}5^{\text {th }} \text { Percentile } \\
(\mathrm{cm})\end{array}$ & $\begin{array}{l}50^{\text {th }} \text { Percentile } \\
(\mathrm{cm})\end{array}$ & 75th Percentile $(\mathrm{cm})$ & $\begin{array}{l}\text { 95th Percentile } \\
\text { (cm) }\end{array}$ \\
\hline 1 & Cabin Height & 20 & 5.737305 & 198.75 & 192.6 & 199.5 & 203.25 & 203.85 \\
\hline 2 & Cabin width & 20 & 23.38803 & 104.5 & 80.25 & 105 & 120.25 & 128.05 \\
\hline 3 & Cabin Length & 20 & 10.62623 & 122.75 & 109.85 & 127 & 128.5 & 129.7 \\
\hline 4 & Seat to Door distance & 20 & 8.80814 & 17.25 & 10.15 & 15 & 21.5 & 27.5 \\
\hline 5 & Cabin Floor to Ground & 20 & 8.01561 & 103.75 & 94.1 & 106.5 & 107.75 & 109.55 \\
\hline 6 & Pedal to Seat distance & 20 & 7.325754 & 30.5 & 23.6 & 29.5 & 34 & 38.8 \\
\hline 7 & Steering to Floor & 20 & 3.316625 & 72.5 & 70 & 71.5 & 74 & 76.4 \\
\hline 8 & Dashboard to backrest. & 20 & 12.52664 & 81.75 & 69.6 & 82.5 & 92.25 & 92.85 \\
\hline 9 & Steering to Backrest dist. & 20 & 6.531973 & 42 & 35.2 & 42 & 44 & 48.8 \\
\hline 10 & Steering Wheel Diameter & 20 & 9.804081 & 54.7 & 49.49 & 50 & 54.85 & 66.49 \\
\hline 11 & Steering rim thickness & 20 & 1.367175 & 3.525 & 2.475 & 3.1 & 3.85 & 5.17 \\
\hline 12 & Pedal Angle & 20 & 7.465197 & 133.125 & 124.375 & 135 & 136.25 & 139.25 \\
\hline 13 & Steerg rack angle & 20 & 2.954516 & 76.125 & 73.3 & 75.75 & 77.375 & 79.475 \\
\hline 14 & Door width & 20 & 0.707107 & 79.5 & 79.05 & 79.5 & 79.75 & 79.95 \\
\hline 15 & Door height & 20 & 12.72792 & 165 & 156.9 & 165 & 169.5 & 173.1 \\
\hline 16 & Dashboard to Seat distance & 20 & 2.828427 & 28 & 24.6 & 29 & 30 & 30 \\
\hline 17 & Gear lever to Seat distance & 20 & 10.78579 & 20.5 & 8.25 & 22 & 25.25 & 30.65 \\
\hline 18 & Total Height from ground & 20 & 0 & 310 & 310 & 310 & 310 & 310 \\
\hline 19 & Steering rack to Seat dist. & 20 & 14.84363 & 30.5 & 13.95 & 33.5 & 42.25 & 42.85 \\
\hline 20 & Pedal to seat distance & 20 & 21 & 50.5 & 28.1 & 54 & 68 & 68 \\
\hline
\end{tabular}


Continuation Table 4

\begin{tabular}{lllllllcc}
\hline $\mathbf{2 1}$ & SRP to Steering (Horiz.) & 20 & 2.061553 & 54.75 & 52.45 & 55 & 55.5 & 24 \\
$\mathbf{2 2}$ & SRP to Steering (Vertical) & 20 & 2.217356 & 23.75 & 22.15 & 23 & 26.4 & 90.5 \\
$\mathbf{2 3}$ & SRP to Pedal (Horizontal) & 20 & 4.924429 & 88.25 & 82.35 & 90 & 4.7 \\
\hline $\mathbf{2 4}$ & SRP to Pedal (Vertical) & 20 & 2.986079 & 42.75 & 40.3 & 42 & 43.25 \\
\hline
\end{tabular}

Table 5

Summary of data obtained from midi bus Drivers' Seats (category B)

\begin{tabular}{|c|c|c|c|c|c|c|c|c|}
\hline $\mathrm{S} / \mathrm{N}$ & VARIABLE & No. & STDEV & MEAN $(\mathrm{cm})$ & $5^{\text {th }}$ Percentile & $50^{\text {th }}$ Percentile & $75^{\text {th }}$ Percentile & $95^{\text {th }}$ Percentile \\
\hline 1 & Floor to seat Height & 20 & 2.061553 & 41.25 & 39.15 & 41.5 & 43 & 43 \\
\hline 2 & Seatpan thickness & 20 & 2.362908 & 11.75 & 10 & 11 & 12.75 & 14.55 \\
\hline 4 & Seatpan back width & 20 & 4.358899 & 41.5 & 38 & 40.5 & 44 & 46.4 \\
\hline 5 & Backrest Angle & 20 & 7.371115 & 102.5 & 95.2 & 102 & 104.5 & 110.5 \\
\hline 6 & Backrest thickness & 20 & 2.629956 & 10.25 & 8 & 10 & 12.25 & 12.85 \\
\hline 7 & $\begin{array}{l}\text { Backrest width } \\
\text { (lowback level) }\end{array}$ & 20 & 3.855161 & 48.67 & 45.728 & 47.5 & 50.25 & 53.25 \\
\hline 8 & $\begin{array}{l}\text { Backrest width } \\
\text { (Shoulder level) }\end{array}$ & 20 & 4.391001 & 39.4675 & 34.6 & 40 & 42.4675 & 43.5895 \\
\hline 9 & Headrest Angle & 15 & 28.30783 & 127.3333 & 110.2 & 112 & 136 & 155.2 \\
\hline 10 & Headrest width & 15 & 1.921909 & 27.78667 & 26.568 & 26.82 & 28.41 & 29.682 \\
\hline 11 & Headrest height(with stand) & 15 & 1.732051 & 37 & 35.3 & 38 & 38 & 38 \\
\hline 12 & Headrest height(no stand) & 15 & 2 & 22 & 20.2 & 22 & 23 & 23.8 \\
\hline 16 & Seat Depth & 20 & 5 & 47.5 & 41.5 & 50 & 50 & 50 \\
\hline 17 & Backrest Height & 20 & 5.057997 & 44.25 & 38.75 & 44.5 & 47 & 49.4 \\
\hline 18 & SRP to Steering (Horizontal) & & 2.061553 & 54.75 & 52.45 & 55 & 55.5 & 56.7 \\
\hline 19 & SRP to Steering (Vertical) & & 2.217356 & 23.75 & 22.15 & 23 & 24 & 26.4 \\
\hline 20 & SRP to Pedal (Horizontal) & & 4.924429 & 88.25 & 82.35 & 90 & 90.5 & 91.7 \\
\hline 21 & SRP to Pedal (Vertical) & & 2.986079 & 42.75 & 40.3 & 42 & 43.25 & 46.25 \\
\hline
\end{tabular}

Table 6

Summary of the Anthropometric Dimensions of 150 Nigerian Male Urban Bus Drivers Length/Height (cm), Angles (degree)

\begin{tabular}{|c|c|c|c|c|c|c|c|c|c|c|}
\hline & VARIABLE & No. & MEAN & STD.DEV. & $\begin{array}{c}5^{\text {th }} \\
\text { Percentile }\end{array}$ & $\begin{array}{c}50^{\text {th }} \\
\text { Percentile }\end{array}$ & $\begin{array}{c}75^{\text {th }} \\
\text { Percentile }\end{array}$ & $\begin{array}{c}95^{\text {th }} \\
\text { Percentile }\end{array}$ & MIN. & MAX. \\
\hline P1 & Stature & 150 & 173.15 & 3.32473 & 168.8 & 173 & 175.5 & 179.1 & 166 & 180 \\
\hline P2 & Sitting Height & 150 & 83.175 & 4.51713 & 76.9 & 83 & 86.25 & 90 & 74 & 91 \\
\hline P3 & $\begin{array}{l}\text { Eye-Floor } \\
\text { height }\end{array}$ & 150 & 73.4 & 5.2315 & 60 & 77 & 81 & 83.15 & 50 & 88 \\
\hline P4 & Shoulder Width & 150 & 44.5 & 3.25458 & 40 & 44 & 46.2 & 50 & 39 & 51 \\
\hline P5 & $\begin{array}{l}\text { Shoulder } \\
\text { Height }\end{array}$ & 150 & 55.395 & 1.96898 & 53 & 55 & 56 & 58.15 & 53 & 62 \\
\hline P6 & Shoulder-Elbow & 150 & 34.6125 & 1.90642 & 31.475 & 35 & 36 & 37.05 & 31 & 38 \\
\hline P7 & Knee Height & 150 & 59.25 & 1.48497 & 56.95 & 59 & 60 & 61.05 & 55 & 62 \\
\hline P8 & Elbow-Wrist & 150 & 30.2875 & 1.34873 & 28 & 30 & 31 & 33 & 28 & 33 \\
\hline P9 & Knee Length & 150 & 60.7125 & 1.67901 & 57.95 & 61 & 62 & 63 & 57 & 63 \\
\hline P10 & $\begin{array}{l}\text { Popliteal } \\
\text { Length }\end{array}$ & 150 & 48.75 & -1.4456 & 49.95 & 49 & 50 & 50 & 45 & 51 \\
\hline P11 & Hip Breadth & 150 & 37.0175 & 1.97975 & 34.7 & 37 & 38 & 40.145 & 32.4 & 41 \\
\hline P12 & Tommy Depth & 150 & 20.3325 & 3.06171 & 14.93 & 21 & 22.4 & 25 & 11.7 & 25 \\
\hline P13 & $\begin{array}{l}\text { Popliteal- } \\
\text { Height }\end{array}$ & 150 & 47.4625 & 1.21628 & 46 & 47.5 & 48 & 50 & 45.5 & 50 \\
\hline P14 & Foot Length & 150 & 26.5275 & 0.83297 & 25 & 26.4 & 27.1 & 28 & 25 & 28 \\
\hline P15 & Foot Breadth & 150 & 9.5175 & 0.73794 & 8.395 & 9.7 & 10 & 10525 & 8.2 & 11.2 \\
\hline P16 & Hand Length & 150 & 20.0575 & 0.70234 & 19 & 20 & 20.625 & 21 & 18.8 & 21 \\
\hline P17 & Hand Breadth & 150 & 9.745 & 0.57466 & 8.99 & 10 & 10 & 10.505 & 8.7 & 11 \\
\hline P18 & $\begin{array}{l}\text { Shoulder - } \\
\text { Wrist }\end{array}$ & 150 & 64.8 & 2.93258 & 60.475 & 65 & 67 & 70 & 60 & 70 \\
\hline P19 & Head Breadth & 150 & 14.975 & 0.73441 & 13.895 & 14.95 & 15.525 & 16 & 13.8 & 16.1 \\
\hline P20 & Head Length & 150 & 20.2075 & 0.98668 & 19 & 19.9 & 21 & 22 & 19 & 22 \\
\hline P21 & $\begin{array}{l}\text { Tommy - } \\
\text { Steering }\end{array}$ & 150 & 19.7 & 3.18812 & 15.95 & 19.5 & 22 & 24.1 & 15 & 26 \\
\hline
\end{tabular}


Continuation Table 6

\begin{tabular}{|c|c|c|c|c|c|c|c|c|c|c|}
\hline P22 & $\begin{array}{l}\text { Chest - } \\
\text { Steering }\end{array}$ & 150 & 32.2 & 2.94566 & 27 & 33 & 34 & 36 & 26 & 38 \\
\hline P23 & $\begin{array}{l}\text { Right knee - } \\
\text { Dash Board }\end{array}$ & 150 & 12.45 & 2.26399 & 9 & 12 & 15 & 16 & 9 & 16 \\
\hline P24 & $\begin{array}{l}\text { Left knee -Dash } \\
\text { Board }\end{array}$ & 150 & 12.95 & 2.34193 & 10 & 12 & 15 & 16.05 & 10 & 17 \\
\hline P25 & $\begin{array}{l}\text { Knee-Steering } \\
\text { Rack }\end{array}$ & 150 & 8.275 & 1.88431 & 5.5 & 8 & 10 & 11 & 5.5 & 11 \\
\hline P26 & $\begin{array}{l}\text { Elbow Angle, } \\
\text { with Steering }\end{array}$ & 150 & 144.188 & 3.88073 & 140 & 144.25 & 146 & 147.15 & 139.5 & 162 \\
\hline P27 & $\begin{array}{l}\text { Elbow Angle } \\
\text { with Gear }\end{array}$ & 150 & 165.3 & 3.37563 & 160 & 166 & 168 & 171 & 158 & 171 \\
\hline P28 & $\begin{array}{l}\text { Knee Angle } \\
\text { foot on Floor }\end{array}$ & 150 & 123.075 & 1.91669 & 120.95 & 123 & 123.25 & 126.025 & 120 & 130 \\
\hline P29 & $\begin{array}{l}\text { Ankle Angle } \\
\text { foot on Pedal }\end{array}$ & 150 & 95.675 & 4.74686 & 91 & 94 & 98 & 104.25 & 91 & 110 \\
\hline P30 & $\begin{array}{l}\text { Back angle } \\
\text { Sitting }\end{array}$ & 150 & 100.975 & 4.02229 & 96 & 101 & 102.25 & 111.05 & 96 & 112 \\
\hline
\end{tabular}

Table 2 shows the summary of data obtained from mini bus workstation (category A), while Table 4 shows the summary of data obtained from midi bus workstation (category B).. In the tables, the 5th 50th, 75th and 95th percentiles of the horizontal and vertical distances of the steering wheel/pedal from the seat reference point (SRP) were stated.

The percentile value was in the range $42.50-55.75 \mathrm{~cm}$ for the horizontal distance of the centre of steering wheel to the seat reference point for category ' $A$ ' buses. For category $B$, the range was $52.45-56.70 \mathrm{~cm}$. Table 2 showed that the percentile value range of the vertical distance of the steering wheel from the SRP for buses in category A was given as 30 $-35 \mathrm{~cm}$ while, for the midi buses in category $B$ as it appeared in Table 4 was between 22.15 and $26.40 \mathrm{~cm}$. Table 2 also showed that the value range of the vertical distance of the pedal from the SRP for small buses (A) is $25-30 \mathrm{~cm}$; while Table 4 revealed that the range for midi buses (B) was $40.30-46.25 \mathrm{~cm}$ Category A buses as in Table 2, the horizontal distance of the SRP to the pedal was within the range of $87.25-94.75 \mathrm{~cm}$ while that of category $B$ in Table 4 is $82.35-91.7 \mathrm{~cm}$. Tables 3 and Table 5 show the results obtained from the driver's seat data analysis for the two categories $A$ and $B$ of buses considered in this research work respectively. Table 3 revealed that 5th and 95th percentiles value range for the seat height from the cabin floor is $25.5-40.25 \mathrm{~cm}$ for category A buses while Table 5 showed that 39.15 - $43 \mathrm{~cm}$ for category B. Table 6 showed the results obtained for the popliteal height of range $46-50 \mathrm{~cm}$ from the anthropometric data analysis of the drivers. Table 3 showed the value range of the seat pan depth for category A as $49-50 \mathrm{~cm}$ while the range for category $B$ in Table 5 is $41.5-50 \mathrm{~cm}$.

Meanwhile, Table 3 showed that give the back width range of $38-44 \mathrm{~cm}$, while Table 5 depicts the back width range of $38-46.4 \mathrm{~cm}$ showing slightly wider dimensions when compared to the drivers' hip width range of $34.70-40.15 \mathrm{~cm}$ in table 9 . However, the seatpan front width range is $48.5-53 \mathrm{~cm}$ for category $A$ and the range for category $B$ is $47.15-49.7 \mathrm{~cm}$. The backrests have different width dimensions at the low back and shoulder levels. The shoulder level range for category $A$ is $42.25-47.5 \mathrm{~cm}$ and 34.6 $43.6 \mathrm{~cm}$ for B. Tables 3 and Table 5 again failed to accommodate 95th percentile of shoulder breadth $(50 \mathrm{~cm})$ dimensions of the sampled drivers' population shown in Table 6 . Table 3 and Table 5 showed the ranges for the lumber level are $47-51.5 \mathrm{~cm}$ for category $A$ and $45.73-53.25 \mathrm{~cm}$ for category $B$. The backrest height is determined by the shoulder height sitting. However, the backrest height result for category $A$ of $(50-57.35 \mathrm{~cm})$ seems to 
be lower to the anthropometric value range of the shoulder height $(53-58.5 \mathrm{~cm})$ than that of category B (38.75 - 49.4cm), which is rather too short for the Nigerian driver to work with comfortably and efficiently.

Table 5 reveals that none of the midi buses in category B has an armrest; while table 3 of the category A buses gives only constant values for the armrest parameters. Headrest provides support for the head while driving. Table 3 gives the height value range of $16-35 \mathrm{~cm}$ for category A buses while category B has $(20.2-23.8 \mathrm{~cm})$ as in table 5 . The headrest widths for the two categories in tables 3 and table 5 showed that Category $A$ buses has the width range of $22-32 \mathrm{~cm}$, and those in category $B$ have $26.6-29.7 \mathrm{~cm}$ range. Meanwhile, the head widths of the drivers are within 13.89 and $16 \mathrm{~cm}$ range according to Table 6 (P19) of the anthropometric dimension of 150 bus drivers'. It is to be noted that the backrest for one bus brand in that category $B$ has no headrest.

Table 7

\section{Comparisons of Drivers' Seats Structural Dimensions for Categories 'A' and 'B' and the Current Study Values}

\begin{tabular}{|c|c|c|c|c|c|}
\hline S/N & SEAT PARAMETER & CATEGORY A (cm) & $\begin{array}{l}\text { CATEGORY B } \\
(\mathrm{cm})\end{array}$ & $\begin{array}{l}\text { Current study } \\
\text { Value }(\mathrm{cm})\end{array}$ & Determinant \\
\hline 1 & Floor to Seat height & $25.5-40.25$ & $39.15-43$ & $46-50$ & Popliteal height \\
\hline 2 & Seatpan depth / length & $49-50$ & $41.5-50$ & $49.95-50.00$ & Popliteal length \\
\hline 3 & Seatpan (back) width & $38-44$ & $38-46.4$ & $334.7-40.15$ & Hip width \\
\hline 5 & Backrest width ( low back level) & $47-51.5$ & $45.73-53.25$ & $34.7-40.15$ & Hip width \\
\hline 6 & Backrest width (shoulder level) & $42.25-47.5$ & $34.6-43.59$ & $40-50$ & Shoulder width \\
\hline 7 & Backrest height & $50-57.25$ & $38.75-49.4$ & $53-58.15$ & Shoulder height \\
\hline 8 & Armrest length(Right Hand only) & 30 (Honda only) & None & $47-54$ & Elbow to wrist length \\
\hline 9 & Armrest height(Right Hand only) & $11-19$ & None & $15.9-27,5$ & Shoulder to elbow \\
\hline 10 & Armrest width(Right Hand only) & 7 (Honda only) & None & $8-12$ & Hand Width \\
\hline 11 & Headrest height & $\begin{array}{c}16-35 \\
\text { (adjustable) }\end{array}$ & $20.2-38$ & $18.75-37$ & Shoulder to head \\
\hline 12 & Headrest width & $22-32$ & $26.6-29.7$ & $13.89-16$ & Shoulder width \\
\hline
\end{tabular}

Note

Category A \& B is a direct measurement

Current study is the anthropometric data obtained from the drivers'.

Relevant design dimensions of the driver's compartment and seats had been collected and analysed from 6 brands mini buses and 4 brands of midi buses operating in south western Nigeria. The data collected were summaries and recorded in Tables 8 - 12 . The results obtained were compared with relevant researchers and useful inferences drawn.

\section{Comparison of drivers' anthropometric (Mean) dimensions of the current study and previous related study}

\begin{tabular}{llccc}
\hline & $\begin{array}{c}\text { Anthropometric Data } \\
\text { Mean }(\mathbf{c m})\end{array}$ & $\begin{array}{c}\text { Current Study } \\
(\mathbf{c m})\end{array}$ & $\begin{array}{c}\text { Ajayeoba (2009) } \\
(\mathbf{c m})\end{array}$ & $\begin{array}{c}\text { Onuoha (2012) } \\
\text { (cm) }\end{array}$ \\
\hline $\mathbf{1}$ & Stature & 173.15 & 173.30 & 163.4 \\
$\mathbf{2}$ & Hand length & 20.06 & & 18.6 \\
$\mathbf{3}$ & Hand breadth & 9.75 & & 8.2 \\
\hline $\mathbf{4}$ & Popliteal height & 49.46 & $49 / 8$ & 43.4 \\
$\mathbf{5}$ & Buttock to Popliteal & 48.75 & 48.9 & 48.2 \\
\hline
\end{tabular}




\begin{tabular}{clccc}
\hline 6 & Shoulder breadth & 44.50 & 42.8 & 43.1 \\
\hline 7 & Hip breadth & 37.02 & 34.9 & 29.0 \\
\hline 10 & Elbow to wrist & 30.29 & & 29.8 \\
\hline 12 & Shoulder height & 55.4 & 57.1 & 54.2 \\
\hline 13 & Shoulder to elbow & 34.61 & 36.2 & 31.0 \\
\hline 14 & Sitting Height Erect & 83.18 & & 83.7 \\
\hline 15 & Knee length & 60.71 & 58.1 & 58.3 \\
\hline 16 & Knee height & 59.22 & & 52.8 \\
\hline 17 & Eye to floor height & 73.40 & & 74.6 \\
\hline 18 & Elbow rest height & 24.6 & & 24.3 \\
\hline 19 & Back to knee & 55.6 & & 58.0 \\
\hline 20 & Foot length & 26.53 & & 24.9 \\
\hline
\end{tabular}

Table 9

Comparison of relevant anthropometric variables of the current study and some other countries of the world

\begin{tabular}{|c|c|c|c|c|c|c|c|c|c|c|c|c|c|c|}
\hline \multirow{2}{*}{$\begin{array}{l}\text { Anthropometric } \\
\text { Variable } \\
\text { (cm) }\end{array}$} & \multicolumn{2}{|c|}{$\begin{array}{l}\text { South-Western Nigeria } \\
\text { (present study) }\end{array}$} & \multicolumn{2}{|c|}{ Germany** } & \multicolumn{2}{|c|}{ Japan** } & \multicolumn{2}{|c|}{ China** } & \multicolumn{2}{|c|}{ Britain $^{* *}$} & \multicolumn{2}{|c|}{ Russia** } & \multicolumn{2}{|c|}{ Philippines** } \\
\hline & Mean $(\mathrm{cm})$ & S.D & $\begin{array}{l}\text { Mean } \\
(\mathrm{cm})\end{array}$ & S.D & $\begin{array}{l}\text { Mean } \\
(\mathrm{cm})\end{array}$ & S.D & $\begin{array}{l}\text { Mean } \\
(\mathrm{cm})\end{array}$ & S.D & $\begin{array}{l}\text { Mean } \\
(\mathrm{cm})\end{array}$ & S.D & $\begin{array}{l}\text { Mean } \\
(\mathrm{cm})\end{array}$ & S.D & $\begin{array}{l}\text { Mean } \\
(\mathrm{cm})\end{array}$ & S.D \\
\hline Stature & 173.15 & 3.3 & 171.5 & 6.6 & 168 & 5.5 & 170.5 & 5.9 & 174 & 7.0 & 173.6 & 6.1 & 186.7 & N/A \\
\hline $\begin{array}{l}\text { Sitting Height } \\
\text { erect }\end{array}$ & 83.18 & 4.6 & 90.3 & 3.4 & 91 & 3.0 & 91.0 & 3.0 & 91 & 3.6 & 90.9 & 3.2 & 86.4 & N/A \\
\hline Sitting Eye Height & 73.4 & 9.23 & 77.5 & 3.4 & 79 & 2.9 & 79.1 & 2.9 & 79.0 & 3.5 & 79.1 & 3.2 & 76.1 & N/A \\
\hline $\begin{array}{l}\text { Sitting Shoulder } \\
\text { Height }\end{array}$ & 55.40 & 1.9 & 60.1 & 3.1 & 59.1 & 2.6 & 60.2 & 2.6 & 59.5 & 3.2 & $\mathrm{~N} / \mathrm{A}$ & $\mathrm{N} / \mathrm{A}$ & 56.9 & N/A \\
\hline $\begin{array}{l}\text { Sitting elbow } \\
\text { Height }\end{array}$ & 20.8 & N/A & 24.4 & 2.9 & 25.4 & 2.3 & 26.4 & 2.4 & 24.5 & 3.1 & 24.1 & 2.6 & 24.6 & N/A \\
\hline Thigh Clearance & N/A & N/A & 15.1 & 1.5 & 15.6 & 1.2 & N/A & N/A & 16.0 & 1.5 & 14.6 & 1.6 & 15.5 & N/A \\
\hline Knee height & 59.25 & 1.5 & 53.1 & 2.7 & 50.9 & 2.2 & 52.1 & 2.9 & 54.5 & 3.2 & 55.0 & 2.5 & 52.8 & $\mathrm{~N} / \mathrm{A}$ \\
\hline Popliteal height & 47.46 & 1.2 & 45.2 & 2.6 & 40.2 & 1.9 & 41.1 & 1.9 & 44.0 & 2.9 & 45.0 & 2.2 & 47.5 & N/A \\
\hline Shoulder to elbow & 34.61 & 1.9 & N/A & & 33.7 & 1.8 & 33.8 & 1.9 & 36.5 & 2.0 & N/A & N/A & 32.00 & N/A \\
\hline $\begin{array}{l}\text { Elbow to finger } \\
\text { tips }\end{array}$ & 50.33 & N/A & 46.5 & 2.0 & 44.8 & 1.8 & 42.7 & 2.7 & 47.5 & 2.1 & 45.3 & N/A & 46.2 & N/A \\
\hline Forward grips & 87.94 & $\mathrm{~N} / \mathrm{A}$ & 76.3 & 3.7 & $\mathrm{~N} / \mathrm{A}$ & $\mathrm{N} / \mathrm{A}$ & 71.0 & 3.6 & 78.0 & 3.4 & 60.1 & 3.6 & $\mathrm{~N} / \mathrm{A}$ & N/A \\
\hline knee Length & 60.71 & 1.68 & 60.3 & 2.7 & 56.7 & 2.3 & 55.8 & 3.1 & 59.5 & 3.1 & N/A & 3.1 & N/A & N/A \\
\hline Popliteal Length & 48.75 & -1.4 & 48.6 & 2.5 & N/A & N/A & N/A & $\mathrm{N} / \mathrm{A}$ & 49.5 & 3.2 & 45.0 & $\mathrm{~N} / \mathrm{A}$ & 47.2 & $\mathrm{~N} / \mathrm{A}$ \\
\hline Shoulder breadth & 44.5 & 3.25 & 47.1 & 2.4 & N/A & N/A & 46.0 & 2.3 & 46.5 & 2.8 & 34.8 & 2.2 & 41.4 & N/A \\
\hline Hip width sitting & 37.02 & 1.98 & 36.9 & 2.2 & 37.9 & 1.9 & 36.0 & $2 . .7$ & 36.8 & 2.9 & 22.0 & 2.4 & 40.9 & N/A \\
\hline Foot length & 26.52 & N/A & 26.4 & 1.3 & 25.1 & 1.1 & N/A & N/A & 26.8 & 1.4 & 28.0 & 1.2 & 25.7 & N/A \\
\hline Foot breadth & 9.5 & N/A & 10.2 & $6 . .0$ & 10.4 & 0.5 & N/A & N/A & 9.5 & 0.6 & N/A & N/A & 10.4 & N/A \\
\hline Hand length & 20.07 & 0.7 & N/A & N/A & N/A & N/A & N/A & N/A & $\mathrm{N} / \mathrm{A}$ & N/A & N/A & N/A & 18.8 & N/A \\
\hline Hand width & 9.75 & 0.57 & $\mathrm{~N} / \mathrm{A}$ & $\mathrm{N} / \mathrm{A}$ & $\mathrm{N} / \mathrm{A}$ & N/A & N/A & N/A & $\mathrm{N} / \mathrm{A}$ & N/A & $\mathrm{N} / \mathrm{A}$ & N/A & 10.9 & N/A \\
\hline Shoulder Height & 55.40 & 1.97 & N/A & N/A & N/A & N/A & N/A & N/A & N/A & N/A & N/A & N/A & 56.9 & N/A \\
\hline
\end{tabular}

Source: ${ }^{* *}$ Onawumi and Lucas [15]

Table 8 showed the comparison of the drivers' anthropometric dimension in the present study with other researchers. Table 9 shows the comparison of relevant anthropometric variables of adult male Urban Bus drivers in South Western Nigeria obtained in this study with the male adults in other countries such as Germany, Japan, China, Britain, Russia and Philippines. Tables 9, 10 and table 11 showed the comparison of the present study with [13], [15], [16].

From Tables 8, 9 and table 11, it can be deduced that the mean values obtained in this study compared favourably with the range of values procured earlier by Ajayeoba and Adekoya [13], [15] for most parameters. Table 8 revealed that the research of Onuoha et al.,[16] for the south - eastern Nigerian drivers were slightly different because they were obtained from another ethnic group and environment in the same country. 
Analysis of Seat Dimensions and Relevant Drivers' Anthropometric Dimensions in this Study

\begin{tabular}{|c|c|c|c|c|c|c|c|}
\hline \multirow{3}{*}{ Parameter } & \multicolumn{4}{|c|}{ Seat Dimensions } & \multicolumn{3}{|c|}{ Drivers' Anthropometric Data } \\
\hline & \multicolumn{2}{|c|}{ BUS (A) } & \multicolumn{2}{|c|}{ BUS (B) } & \multirow[t]{2}{*}{ Relevant Parameter } & \multirow[b]{2}{*}{ Mean } & \multirow[b]{2}{*}{ SD } \\
\hline & Mean & SD & Mean & SD & & & \\
\hline Seat height & 32.67 & 6.09 & 41.3 & 2.06 & Popliteal height & 47.46 & 1.22 \\
\hline Seat length & 49.62 & 0.52 & 47.5 & 5.0 & Buttock - popliteal & 48.75 & 1.45 \\
\hline Seat width & 41.0 & 2.76 & 41.5 & 4.6 & Hip width & 37.02 & 1.98 \\
\hline Back rest height & 53.67 & 3.14 & 44.3 & 5.05 & shoulder height & 55.40 & 1.97 \\
\hline $\begin{array}{l}\text { Back rest width (lumbar } \\
\text { level) }\end{array}$ & 49.0 & 48.67 & 48.7 & 3.8 & Shoulder breadth & 44.50 & 3.25 \\
\hline $\begin{array}{l}\text { Backrest width(thoracic } \\
\text { level) }\end{array}$ & 44.5 & 39.46 & 39.5 & 4.39 & Hip width & 37.02 & 1.98 \\
\hline Head rest height & 23 & 8.4 & 22.0 & 2.0 & Shoulder height & 27.78 & $\mathrm{~N} / \mathrm{A}$ \\
\hline Head rest width & 26.5 & 4.09 & 27.8 & 1.92 & Shoulder breadth & 44.56 & 3.25 \\
\hline
\end{tabular}

Table 11

Comparison of Workstation Dimensions in this Study with Related Results by Ajayeoba and Adekoya, [13

\begin{tabular}{llcccc}
\hline S/N & \multirow{2}{*}{ Workstation Parameter } & \multicolumn{2}{c}{ Current (Study) } & \multicolumn{2}{c}{$\begin{array}{c}\text { Ajayeoba and Adekoya, } \\
\text { 2010 (Molue buses)* }\end{array}$} \\
\hline & & $\begin{array}{c}\text { Mini Bus } \\
\text { (A) } \mathbf{~ c m ~}\end{array}$ & $\begin{array}{c}\text { Large Bus } \\
\text { (B) } \mathbf{~ c m}\end{array}$ & $\begin{array}{c}\text { Small Molue } \\
\text { Bus (A) } \mathbf{~ c m ~}\end{array}$ & $\begin{array}{c}\text { Big Molue } \\
\text { Bus (B) } \mathbf{~ c m ~}\end{array}$ \\
\hline $\mathbf{1}$ & Pedal to seat & 42.82 & 30.5 & 43.17 & 38.7 \\
$\mathbf{2}$ & Dash board to back rest & 77.5 & 81.75 & 72.1 & 74.8 \\
\hline $\mathbf{3}$ & Door width & 113.33 & 79.5 & 52.3 & 54.8 \\
\hline $\mathbf{4}$ & Door height & 134.83 & 165 & 130.7 & 188.7 \\
\hline $\mathbf{5}$ & Door step to Road & 59 & 63.75 & 49.2 & 49.3 \\
$\mathbf{6}$ & Steering wheel thickness & 3.58 & 3.525 & 3.3 & 3.3 \\
\hline $\mathbf{7}$ & Steering wheel diameter & 40.5 & 54.7 & 41.8 & 55.3 \\
\hline
\end{tabular}

Source: *Ajayeoba and Adekoya, [13].

Table 12

Comparison of Seat Data in this study with those in a related work

\begin{tabular}{|c|c|c|c|c|c|}
\hline & & \multicolumn{2}{|c|}{ (URBAN BUS) } & \multicolumn{2}{|c|}{ (MOLUE)* } \\
\hline & \multirow[t]{2}{*}{ SEAT VARIABLE } & \multicolumn{2}{|c|}{ Current Study } & \multicolumn{2}{|c|}{ Ajayeoba and Adekoya [13] } \\
\hline & & $\begin{array}{l}\text { Mini Bus } \\
\text { (A) }\end{array}$ & $\begin{array}{l}\text { Large Bus } \\
\text { (B) }\end{array}$ & Small Molue (A) & $\begin{array}{l}\text { Big Molue } \\
\text { (B) }\end{array}$ \\
\hline 1 & Seat height & 32.67 & 41.25 & 34.5 & 41.8 \\
\hline 2 & Seat length & 49.67 & 47.5 & 42.4 & 50.5 \\
\hline 3 & Seat width & 41.00 & 41.5 & 42.1 & 46.5 \\
\hline 4 & Backrest width (shoulder) & 49.00 & 48.67 & 41.7 & 50.0 \\
\hline 5 & Backrest height & 53.67 & 44.25 & 43.9 & 50.8 \\
\hline
\end{tabular}

Source: *Ajayeoba and Adekoya [13].

Similarly, table 9, could be inferred that generally there were notable differences in the mean values obtained in this present study and those from the six other countries of the world (Germany, Japan, China, Philippines, Russia and Britain). This corroborates with the findings of Hedge [17], that people from different ethnics groups have proportionally 
different characteristics. This study also revealed that Japanese adult males have shorter mean $(168 \pm 5.5 \mathrm{~cm})$ stature than the south western Nigeria adult male $(173.15 \pm 3.3 \mathrm{~cm}) .$. In addition, the Nigerian males have longer elbow to finger tip/ forward grip and higher popliteal height than their counter parts in Germany, Japan, China, Britain and Russia.

Table 9 showed the differences between stature and sitting height (erect) also suggest that adults in south western Nigerians had shorter lower limbs $983.18 \pm 4.6 \mathrm{~cm}$ ) than their counterparts in the other countries. This confirms the findings of Hedge [17] that most Africans have shorter lower limbs than the Europeans. This will therefore have direct impacts on the placement of both the hand and leg control devices in the drivers' workstation as well as the dimension of the seat height.

However, the dimensions of the hip widths, foot length and foot breadth, and popliteal lengths of the south-western Nigerian adult males compared favourably with those of Germans, Japanese, Chinese, Philippines and British except for the Russians whose hip dimensions are smaller. This inferred that there will be a mismatch if the anthropometric data of the citizens of those countries were used to design equipment for southwest Nigerians. Table 10 revealed that there were considerable differences between the anthropometric dimensions of the Nigerian bus drivers and the seat dimensions in the two categories A and B of the selected buses. Meanwhile, Parcells et.al,.[18] suggested that a chair whose seat height is $>95 \%$ or $<88 \%$ of popliteal height is a mismatch for the user. They also suggested that if the seat length is $>95 \%$ or $<80 \%$ of the buttock - popliteal length and then the seat is a mismatch for the user.[19].

Therefore, table 10 showed that mismatches exist between the popliteal Height and seat height, buttock to popliteal length and seat length as well as between hip width and the seat width. For mini buses $(A)$ - the mean height is $68.8 \%(<88 \%)$ of the mean popliteal height. This implies that the seat was too low for the users hence, uncomfortable for him as he must bend while sitting on the seat to drive. This posture may result in low back pain and sprain of the thigh as well as driver hitting the knees against the steering wheel.

The mean seat length/depth was $101.8 \%$ (>95\%) of the buttock to popliteal length. This is a mismatch for the user as the seat is longer than the popliteal length of the user. This makes his leg not to touch the floor or the driver has to shift forward so that his leg could touch the floor, and to do that he will lose contact with the back rest. This may have health implication which may be leg, back and shoulder pains. Also, there is a mismatch between the seat width and the hip width. The seat width was $110.8 \%$ (>95\%) of the hip width. Similarly, for large buses in category B, the mean seat height was $86.8 \%(<88 \%)$ of the mean popliteal height having the same effects of being slightly low for the comfort of the Nigerian bus drivers. The side effects may include back pain, spraining ankle, hitting the steering wheel with the tight and the dashboard with the knees. The mean seat length/depth here was $97.4 \%$ (>95\%) of the mean buttock to popliteal length. This is also a mismatch for the user as suggested by Parcells et.al [18]

In the same manner, the results from this study showed that the mean seat width of the driver seat was $41.00 \mathrm{~cm}$ for $37.02 \mathrm{~cm}$ mean hip width of the large bus drivers i.e. 97.43 (>95\%) of the hip width implying a mismatch for the users and leading to back pain and discomfort when in use. Parcells et.al.,(1999) suggested that seat height should not be $<88 \%$ or $>95 \%$ of popliteal height, it then follows that the mean seat height for a mean popliteal height of $47.46 \mathrm{~cm}$ should be between 41.76 and $45.09 \mathrm{~cm}$, rather than 25.50 to $40.25 \mathrm{~cm}$; 
and 39.15 to $43.00 \mathrm{~cm}$ ranges representing the $5^{\text {th }}$ and $95^{\text {th }}$ percentile ranges in mini buses (A) and large buses (B) respectively.

Similarly, for the seat depth/length, Parcells et.al., [18] suggested that good seat depth should not be $<80 \%$ or $>95 \%$ of the buttock - popliteal length. Therefore, ergonomic driver's seat depth for a mean buttock - popliteal length of $48.75 \mathrm{~cm}$, should range between 39.00 and $46.71 \mathrm{~cm}$ rather than 49 to $50 \mathrm{~cm}$ and 41.5 to $50 \mathrm{~cm}$ representing the $5^{\text {th }}$ and $95^{\text {th }}$ percentile in the mini buses $(A)$ and midi buses $(B)$ respectively.

Ismaila et.al, [19] reported that the seat width should be equivalent to 99 percentile of the hip value plus $15 \%$. With this, the ergonomic seat width range should be 41 to 47.15 $\mathrm{cm}$ and not 38 to $44 \mathrm{~cm}$ and 38 to $46.4 \mathrm{~cm}$ representing the $5^{\text {th }}$ and $95^{\text {th }}$ percentile for the mini buses (A) and large buses (B) respectively. This study also noted a mismatch between the anthropometric data of the drivers and the dimensions of the backrest. Some of the seats have square or rectangle shape with short heights. While some assumed a shape of which the lower parts are wider than upper parts. This affects the comfort of the drivers, and may lead to neck and shoulder pains. This study hereby suggests that the ergonomic driver seat should have $95^{\text {th }}$ percentile of the shoulder height for the backrest height, $95^{\text {th }}$ percentile of the shoulder width for the dimension of the upper part; and the seat width dimension for the low back level. This puts the seat dimensions at $58.15 \mathrm{~cm}$ height, upper shoulder level width of $50 \mathrm{~cm}$ and the low back / hip level width of $47.15 \mathrm{~cm}$ rather than the mean height, upper width, low back width of $53.66,49,41.5$; and $44.25,48.67,39.47 \mathrm{~cm}$ in that order for small bus (A) and luxury bus $B$ respectively.

Table 11 and table 12 showed the comparison of the present study with the study of Ajayeoba and Adekoya [13]. The result showed that the pedal-seat of the mini and midi buses in the present study of $42.8 \mathrm{~cm}$ and $30.5 \mathrm{~cm}$ are far apart from $43.17 \mathrm{~cm}$ and $38.7 \mathrm{~cm}$ of the Ajayeoba and Adekoya [13]. The steering wheel thickness was $3.58 \mathrm{~cm}$ and $3.53 \mathrm{~cm}$ for mini and midi buses in the present study as against $3,3 \mathrm{~cm}$ of the Ajayeoba and Adekoya [13]. Table 12 also revealed a drastic different in the seat height of $32.67 \mathrm{~cm}$ and $41.25 \mathrm{~cm}$ mini and midi buses of the present study as compared with $34.5 \mathrm{~cm}$ and $41,8 \mathrm{~cm}$ respectively/.

\section{Conclusions}

The results of the analysis so far conducted showed that there were mismatches between the drivers' anthropometric data and the design measurements of the present driver seats as well as the locations of both hand and foot controls in the drivers' workstations. With reference to the main objective of this study, it could therefore be concluded that the drivers' workstations in the urban buses used in South-West Nigeria were not ergonomically fit for the urban bus drivers in South-West Nigeria since the anthropometric data of the Nigerian male bus drivers were not put into consideration in the designing the buses. According to the objective, the designed data were collected from the drivers' compartments and seats of the selected buses for ergonomic analysis. It could also be concluded that this study had provided appropriate dimension for ergonomic drivers' seat in the urban buses for Nigerian drivers. Similarly, this study had adequately made provisions for ergonomic drivers' seats and appropriate placement of the steering wheels and pedals in the urban buses to be ergonomically suitable for the Nigerian drivers.

Having achieved this, the ergonomic placement of the steering wheel and the pedal, as well as the drivers' seat dimensions within the drivers' workstations to improve the efficiency 
and availability of urban bus drivers within the scope, various numerical results obtained from this analysis are hereby recommended for direct use and also for further ergonomic studies. The anthropometric data are also recommended for other designs and production of safety and clothing materials such as hand glove, foot wear, goggle, and apron for the driver and related populations.

\section{References}

1. Marras W.S. and Karwowski W. 2006. The Occupational Ergonomics Handbook: Interventions, Controls, and Applications in Occupational Ergonomics, 2nd ed.Boca Raton FL: CRC Press.

2. Gibson W.H., Megaw E.D., Young M.S., and Lowe E.B. 2006. "A taxonomy of human communication errors and application to railway track maintenance". Cognition Technology and Work 8:57-66.

3. Stanton N.A. and Salmon P.M. 2009. Human error taxonomies applied to driving: ageneric driver error taxonomy and its implications for intelligent transport systems. Safety Science 47:227-237

4. OSHA (Occupational Safety and Health Administration), 2000 (Revised): Ergonomics: The Study of Work. U.S. Department of LaborParenteau, C., S., Shen,

5. Ismaila S.O. 2010b. An Ergonomics Assessment of Passenger Seats in Buses in South Western Nigeria. Preliminary Communication Sigurnost 52(4):329 - 334

6. Kayis B, Ozok A.F, 1991; The anthropometry of Turkish army men". Applied. Ergon. 22: 49-54.

7. Jeong B.Y, Park K.S, 1990; Sex differences in anthropometry for school furniture Design. Ergonomics 33: 1511-1521.

8. Byran E., Gilad I. and Oxman R. 2013. Ergonomic Design: Experimental Studies of Multi-Task Vehicle. Agriculture Forestry and Fisheries 2(1): 23-32

9. Li G. and Haslegrave C.M. 1999. Seated work postures for manual, visual and combined tasks. Ergonomics 42(8):1060-1086.

10. Kulcsar R.M., Borozan I.S, Argesanu V. and Madaras L. 2013. Car Seats Ergonomic Evaluation. Annals of Faculty ofEngineering Hunedoara International Journal of Engineering. XI (2): 141-146

11. Nkakini S.O., Akor A.J. and Ayotamuno J.M. 2008. Ergonomics of Tractor Operation Control For Comfort In Nigeria, Journal of Agricultural Engineering and Technology (JAET) 16(1):2-11

12. Tan C., Chen W., Delbressine F. and Rauterberg M. 2008. Objectifying Discomfort Seat Measurement for Next Generation Truck Driver's Seat. Designed Intelligence Group, Department of Industrial Design, Technical University Eindhoven, the Netherlands.

13. Ajayeoba, A.O. and. Adekoya, L.O., 2010. Evaluation of the Ergonomic Suitability of Passenger Seats in Molue Buses in Nigeria Journal of Mechanical Engineering 1(2): 4-6

14. Ajayeoba A.O and Adekoya L.O., 2009. Ergonomic Assessment of the Driver compartments of Molue buses in Nigeria. Technical Report.

15. Onawumi A.S. and Lucas E.B. 2012. Ergonomic Investigation of Occupational Drivers and Seat Design of Taxicabs in Nigeria. ARPN Journal of Science and Technology. 2(3):214-220

16. Onuaoha S. N., Idike F. I. and Oduma O. 2012. Anthropometric of Southeastern Nigeria Agricultural workers, International Journal of Engineering and Technology 2(6):1089-1095

17. Hedge A. 2011. Anthropometry and Workspace Design, Cornell University, DEA 3250/6510

18. Parcells C., Stommel M. and Hubbard, R.P., 1999; "Mismatch of classroom furniture and students body dimensions: Empirical findings and health implications”. Journal of Adolescent Health, 24, 265-273.

19. Ismaila S.O. 2010a. A Study on Ergonomics Awareness in Nigeria. Australian Journal of Basic and Applied Sciences. 4(5): 731-734. 